\title{
DEATH, DESPAIR AND SEX: THE PROBLEM OF EVIL ACCORDING TO AUGUSTINE AS A THREEFOLD FOUNDATION OF THE GOOD LIFE
}

\section{MUERTE, DESESPERO Y SEXO: EL PROBLEMA DEL MAL EN AGUSTIIN COMO TRIPLE FUNDAMENTO DE LA VIDA BUENA}

SCHUTIJSER De GROOT, DENNIS ${ }^{1}$

Recibido: 7 de noviembre de 2016 Aprobado: 20 de febrero de 2017

${ }^{1}$ Pontifica Universidad Católica del Ecuador, Facultad de Ciencias Filosófico-Teológicas, Quito, Ecuador, (dschutijser667@puce.edu.ec). 



\section{DEATH, DESPAIR AND SEX: THE PROBLEM OF EVIL ACCORDING TO AUGUSTINE AS A THREEFOLD FOUNDATION OF THE GOOD LIFE}

\section{MUERTE, DESESPERO Y SEXO: EL PROBLEMA DEL MAL EN AGUSTIIN COMO TRIPLE FUNDAMENTO DE LA VIDA BUENA}

Schutijser De Groot, Dennis.

Palabras Clave: San Agustín, Mal, Buen Vivir, Felicidad, Ética

Key Words: Saint Augustine, Evil, Good Life, Happiness, Ethics

\section{RESUMEN}

En lo general, la obra de San Agustín no está asociada con la filosofía del buen vivir tal como se la encuentra tan caracterizada en la antigüedad. Al contrario, el padre de la Iglesia se asocia más bien con un distanciamiento de la existencia terrestre y una disociación de la filosofía con la pregunta ética de la vida feliz. Así se pierde de vista el interés fundamental de Agustín por los orígenes de la pregunta por el buen vivir y la búsqueda de la felicidad.
El presente artículo presenta las interpretaciones del Agustín temprano acerca del problema del mal desde tres enfoques: una aproximación metafísica, una epistemológica y una ética. Desde cada enfoque se puede indicar la forma y el impacto del mal, llevando a una triple propuesta de la vida feliz en respuesta al problema del mal. Así encontramos en Agustín un filósofo aún integrado en la filosofía antigua del buen vivir, con una propuesta basada, 
no en la renunciación de la vida, sino en una toma de posición ética que busca definitivamente responder al problema del mal.

\section{ABSTRACT}

Saint Augustine is not usually associated with the philosophy of the art of living that is so characteristic of antiquity. On the contrary, as a father of the Church, he is rather associated with a turn away from earthly existence and a dissociation of philosophy with the ethical question of the good life. This overlooks Augustine's fundamental interest in the origins of the question for the good life and in the search for happiness.

This article presents the early Augustine's interpretations of the prob- lem of evil from three different angles: a metaphysical, an epistemological, and finally an ethical approach. From each viewpoint, the form and impact of evil may be indicated, subsequently leading to a threefold proposal of the good life in reply to the problem of evil. We thus find in Augustine a philosopher still integrated in the classical philosophy of the art of living, with a proposal based, not in the renunciation of life, but in an ethical stance that seeks to permanently counter the problem of evil.

\section{INTRODUCTION: WHAT IS THE GOOD LIFE AND HOW DO WE ATTAIN IT?}

The philosophical works of Saint Augustine allow for many interrogations and enriching answers, not only towards philosophy as such, nor exclusively towards theology. Although Augustine's works have been explored from both angles beyond measure throughout history, both readings also risk limiting the richness of Augustine's work in general, and his contribution to contemporary thought beyond both theology and philosophy, i.e. neither limited to academic issues such as the nature of time or memory, nor to the essence of God or man as his creation, but answering to such practical questions as "what is the good life?".

Contemporary philosophy has experienced a true revival of this elementary and universal question of the good life, or Beata Vita, often tracing 
its origin back to Ancient philosophy. And indeed, the question of the good life may be considered to have been first formulated by Socrates (Augustine, 1887-2, VIII-iii), and has remained crucial throughout antiquity and the Hellenistic era. ${ }^{2}$ It would be a mistake, however, to think that with the end of Hellenistic philosophy, the question of the good also ceased to be relevant, as is sometimes assumed. ${ }^{3}$ Augustine himself, having been confronted with Hellenistic thought, among which most notably with Cicero, author of the Hortensius, the work that had such a profound impact on Augustine that it can properly be considered a first conversion, that to the pursuit of knowledge ${ }^{4}$, (but also of the Tusculanae Queastiones, De Officiis, and other works on happiness and morality), carried out similar philosophical works as his predecessors. Most notably, the short dialogue De Beata Vita, dedicated to that same popular topic of the good life. In it, Augustine's proposal for a good life is strongly determined by his analysis of evil, offering a threefold reply to a threefold problem.

It is worth briefly mentioning the historical context in which the work is written. The conversation that lies at its basis can in fact be found in the Confessions, when Augustine and some of his closest friends and family members retreat to a landside villa, shortly after the conversion described throughout the Confessions. Augustine is witnessing the decline of the Roman Empire and the rise of Christianity first hand. It is against that Augustine experiences bachgraund his conversion and writes the dialogues and many other earlier works, in which he will lay the basis for his entire Corpus. Although for the long remainder of his life, his thinking will display certain shifts in attention, work out consequences, even retract earlier conclusions, the ancient heritage and the focus on the question of evil, his own experience, and the consequences for his formulation of a good life are most tangible in these early years after his own conversion.

\footnotetext{
${ }^{1}$ The (re-)emergence of the topic of the good life has, incidentally, reached beyond philosophy, having even found articulation in political programs and social debates.

${ }^{2}$ See, for example, P. Hadot, 1995

${ }^{3}$ See for example, A. De Botton, 2000. The author's already limited historical selection jumps from Antiquity straight to Humanist Renaissance. Hadot (1995) defends the thesis that Christian philosophy, especially in its earliest forms, was very much concerned with formulating ideas on the good life.

4 "This book, in truth, changed my affections, and turned my prayers to Yourself, O Lord, and made me have other hopes and desires. Worthless suddenly became every vain hope to me; and, with an incredible warmth of heart, I yearned for an immortality of wisdom, and began now to arise that I might return to You." (Augustine, 1887-1, III-iv-7)
} 
What then is to be Augustine's proposal for a good life, for happiness? As we shall see, the existence and problematic urgency of the experience of evil lay the basis for his proposal. For it is evil, in its diverse forms, that can keep us from attaining the good life, and thus it is to the problem of evil that we need to seek an answer, in order to reply to the question of the good life. For this reason, it is important to first understand what evil is, in order to subsequently understand what "the good" of the good life could be.

\section{THE PROBLEM OF EVIL}

The urgency of the problem of evil plays a central role in Augustine's early thought, reappearing throughout the Confessions ${ }^{5}$, as well as more extensively in his polemical writing Concerning the Nature of Good, Against the Manichaeans. It is hardly an exaggeration to name the problem of evil as a driving motor behind the entire intellectual endeavor of the Hipponian thinker. The urgency most clearly manifests itself in this polemic with the Manicheans, a sect to which Augustine adhered for nearly ten years, for which reason it may be considered that, although he always kept a certain reserve and never climbed in the ranks of the Manichean faith, he did find strong appeal in its doctrines and for a long time pondered the issues it presented and the solutions it offered.
In this mainly metaphysical dispute over the ontological nature of God and evil, the logical problem appears in all its complexity. For, as Augustine states: "The highest good, than which there is no higher, is God, and consequently He is unchangeable good, hence truly eternal and truly immortal. All other good things are only from Him, not of Him. For what is of Him, is Himself." (Augustine, 1887-3, I) Augustine here opposes Manichean dualism, that is, the Manichean doctrine that God is not all powerful, but opposed by a metaphysical counterforce, a demiurge or maker of the material world, who in turn is not good. (Augustine, 1887-3, XLI) Augustine rejects this limitation of God and is thus first to encounter the logical problem of evil in all its force. That logical problem accounts for the impossibility of reconciling three

\footnotetext{
${ }^{5}$ See, for example, the famous theft of the pears (Augustine, 1887-1, II-iv), and the break from Manicheism and the consequent uncertainties Augustine faces ("Where, then, is evil, and whence, and how crept it in hither? What is its root, and what its seed? Or has it no being at all?" (Augustine, 1887-1, VII-V-7)
} 
postulates, all three accepted in full by Augustine and many theologians - and philosophers - after him: 1) God is omnipotent; 2) God is the supreme Good; 3) There is evil in the world. ${ }^{6}$ Manichaeism rejected the first premise, thus avoiding the problem. Philosophers such as Socrates and the stoics rejected the third, explaining away evil as ignorance. But Augustine's God was both omnipotent and supremely good. And, nonetheless, evil exists. It appears fundamentally in two forms: "We usually speak of 'evil' in two ways, namely when someone has (a) done evil; (b) suffered something evil."(Augustine, 2010, 1-1-1-1) In other words, we can distinguish between natural evil (das Schlechte) that befalls us, and moral evil (das Böse) that we as human beings actively commit.

\section{Natural Evil: Death}

The first type of evil, natural evil, is at the heart of the aforementioned paradox of the problem of evil. How is it possible that God, being both all-powerful and supremely good, allows for suffering and death to define our lives? For it is indeed the distinctly human being-toward-death that profoundly disturbs Augustine throu- ghout his intellectual quest, reflected in the first books of the Confessions. Thus he describes his profound suffering when a close friend dies:

\begin{abstract}
"Behold my heart, O my God, behold and see into me; for well I remember it, O my Hope, who cleansest me from the impurity of such affections, directing mine eyes towards Thee, and plucking my feet out of the snare. For I wondered that others, subject to death, did live, since he whom I loved, as if he should never die, was dead; and I wondered yet more that myself, who was to him a second self, could live, he being dead. Well said one of his friend, 'Thou half of my soul'; for I felt that my soul and his soul were'one soul in two bodies': and therefore was my life a horror to me, because I would not live halved. And therefore perchance I feared to die, lest he whom I had much loved should die wholly." (Augustine, 18871, IV-vii-12)
\end{abstract}

Death does not only come to those closest to us; it is that which relates all our fates together. The death of a friend

\footnotetext{
${ }^{6}$ For a short and sharp analysis of the logical problem of evil, see J.L. Mackie, 1955. Notable additions of this formulation of the logical problem are that "omnipotent" is to be taken as meaning that God can indeed do anything at all, i.e. unlimited potency to act; and that good and evil are to be considered true opposites, as in that a truly good being will always seek to rid of any evil (Mackie, 1955, p. 201).

7 "For what would I say, O Lord my God, but that I know not whence I came into this dying life (shall I call it?) or living death." Confessions I-vi-7
} 
reflects my own mortality, reminds me of my own ever imminent death.

As mentioned, the Manichaean solution to the paradox of evil is to not enter into it, by denying its premise concerning the omnipotence of God. Although Manichaeism was one of the dominant religious sects in fourth century Roman Empire, little of its thought and works have been saved. Ironically, it is Augustine's attacks on his former companions that give us one of the most comprehensive insights in Manichean thought. In "Concerning the Nature of Good, Against the Manicheans", Augustine appeals to the followers stating that "[...] if the Manicheans were willing, without pernicious zeal for defending their error, and with the fear of God, to think, they would not most criminally blaspheme by supposing two natures, the one good, which they call God, the other evil, which God did not make [....". (Augustine, 1887-3, 41) Thus, Manichaeism adheres to a strong dualistic metaphysics. Besides a good God, there is an equivalent deity or demiurge responsible for all the evil that exists. Leading up to this refutation of Manichaeism is Augustine's intent to metaphysically found the existence of evil as an absence or privation of good.

First of all, God's omnipotence and the refutation of Manichean dualism leads to the conclusion that all that exists, including everything in the material world, being God's creation, is good. ${ }^{8}$ What then could explain natural evil? Augustine mentions that "every measure, every form, every order" are from God. To explain evil, Augustine elaborates on such an aesthetic frame of reference, stating that "even these privations of things are so ordered in the universe of nature, that to those wisely considering they not unfittingly have their vicissitudes. For by not illuminating certain places and times, God has also made the darkness as fittingly as the day. For if we by restraining the voice fittingly interpose silence in speaking, how much more does $\mathrm{He}$, as the perfect framer of all things, fittingly make privations of things?" (Augustine, 1887-3, XV) In other words, "good" is relative to being and what we call evil is in fact better called a 'lesser good'. In the same way as the good of light needs the darkness in order to be light, and in the same way as darkness is in fact privation of light, in much the same way what we call evil is in fact relative privation of the

\footnotetext{
8 "All life both great and small, all power great and small, all safety great and small, all memory great and small, all virtue great and small, all intellect great and small, all tranquility great and small, all plenty great and small, all sensation great and small, all light great and small, all suavity great and small, all measure great and small, all beauty great and small, all peace great and small, and whatever other like things may occur, especially such as are found throughout all things, whether spiritual or corporeal, every measure, every form, every order both great and small, are from the Lord God." Augustine, 1887-3, XIII
} 
good to which it is related. Thus, our sickness and mortality are the privation of being required to give that being its relative worth - whereas a total absence of being is inconceivable. Our mortality is an evil only to ourselves: from God's viewpoint, it is merely a privation of being that forms part of the total measure, form, and order.

Augustine rejects Manichean metaphysics, but it is this discussion on the metaphysical level that has made a mark on the history of both philosophy and theology, announcing the issue of theodicy (how to overcome the logical incommensurability of God's goodness and omnipotence with the existence of evil) as the dominant treatment of the problem of evil for centuries to come. Whereas this metaphysical approach does not arrive at what really matters. A crucial objection to this metaphysical division of good and evil into a dualist metaphysics, is its moral consequence. For, if a demiurge, equally powerful as God himself, is responsible for the existence of evil in the world, then what should/ could man possibly do against this? Manichean metaphysics results in a moral evasion of responsibility. ${ }^{9}$

\section{Epistemological Evil: from Pride to Despair}

The Manicheans exerted a strong attraction on Augustine because in their doctrine he encountered the same importance he himself attributed to the problem of evil. The given explanation, however, proved unsatisfactory. He would ultimately seek to claim human responsibility for evil, postulating the possibility to knowingly and willingly act wrongfully, i. e. the human tendency toward evil. Before coming to that ethical turn, it is worth mentioning what drove him away from Manicheism. It was not so much the matter of personal responsibility, as it was the conception of God. Manichaeism avoided the logical problem of evil by denying God's omnipotence, reducing God to a powerful being of good, opposed by an equally powerful being of evil. What's more, both of these beings are effectively reduced to beings, i.e. substances. God is not only reduced to one half of a twosome, he is furthermore limited to the horizon of beings, with all the limitations this entails. ${ }^{10}$ In Neoplatonism, Augustine finds the possibility to think of God as something properly transcendental, inclu-

\footnotetext{
${ }^{9}$ It is in opposition to this moral non-responsibility that Augustine will formulate and increasingly accentuate his concept of original sin and of natural evil as a punishment for that original sin. A topic that would lead us too far astray to be dealt with in more detail here.

10 "I thought not of You, O God, under the form of a human body. Since the time I began to hear something of wisdom, I always avoided this; and I rejoiced to have found the same in the faith of our spiritual mother, Your Catholic Church. But what else to imagine You I knew not." Augustine, 1887-1, VII-i-1
} 
ding beyond concepts and beyond our understanding. ${ }^{11}$ Augustine not only turns his back on Manichean metaphysics, but, it could be argued, on metaphysics in general.

An interesting alternative to a metaphysical reading is presented by G.R. Evans in Augustine on Evil. As Evans suggests, "Everything Augustine has to say about evil must be read in the light of one central principle: that the effect of evil upon the mind is to make it impossible for the sinner to think clearly, and especially to understand higher, spiritual truths and abstract ideas". (Evans, 1982, p.29) This epistemological approach to evil explains why it is so hard (and nevertheless important) to discuss with dissenting Christian sects: their vision is blurred and they are therefore incapable of grasping any metaphysical or moral truth, and freeing themselves of evil on an epistemological level. In his Confessions, Augustine informs us of this shift, when he abandons Manicheism and turns to Neoplatonist philosophy, where he finds a truly transcendental (non-)form of God. But philosophy in itself is not enough to solve the epistemological issue. Augustine confesses: "You procured for me, by the instrumentality of one inflated with most monstrous pride, certain books of the Platonists"12, books from which Augustine proceeds to quote Biblical passages much rather than philosophical ones. For, whereas Neoplatonism seems to offer the philosophical foundation for the religious truths of Augustine's Catholicism, the next and final step needs to take us from the (proud) philosophers to the humble believers, and from the logical word to the much more valuable imagery of revelation. Philosophical concepts, in the end, are not enough. What is needed, is to pass to the words of Scripture, "Because You have hid these things from the wise and prudent, and hast revealed them unto babes. ${ }^{13}$

What precisely is the difference between a philosopher's text and the Bible? One possible interpretation is linking both readings to different human experiences. For example, admiring a work of art is quite a different experience from looking at a red traffic light. Although the traffic light will tell me when I can

\footnotetext{
11 "But You, O Lord, I imagined on every part environing and penetrating it, though every way infinite; as if there were a sea everywhere, and on every side through immensity nothing but an infinite sea; and it contained within itself some sponge, huge, though finite, so that the sponge would in all its parts be filled from the immeasurable sea. So conceived I Your Creation to be itself finite, and filled by You, the Infinite." Augustine, 1887-1, VII-v-7

12 Augustine, 1887-1, VII-ix-13

${ }^{13}$ Augustine, 1887-1, VII-ix-14, paraphrasing Matthew 11:25
} 
or cannot cross a street, and therefore contains very useful information for me, I do not look at "Busy New York Street" by Stanislav Sidorov the same way. The difference is, essentially, not between the usefulness of the information it may give me, but in my way of looking as an observer. Looking at a traffic light, I am using the traffic light to my own purposes. The painting however, seems to be using me much rather than I it. I have to submit to the painting, let it dictate to me how it is to be approached, to be seen. In much the same way, the "proud" philosopher attempts to use the concepts he uses for his own purposes, submitting the concepts to his own ends. Scripture requires humility from its reader, not only because Scripture is not reserved for the elite but may also be read by the uneducated, but more importantly because Scripture requires the reader to take on a different stance in reading. The reader of Scripture cannot simply use and abuse the concepts, instead he has to submit to the will of the words, much like submitting to the gaze required by a work of art. ${ }^{14}$

What exactly is the problem in pride, why is it an evil? Not only does it cloud the vision and impede one to perceive the truth beyond the conceptual constructions of philosophy; the proud tend to presume that they do not need God to arrive at comprehension. A clear contradiction, considering the transcendental nature of God found in opposition to the Manicheans: for how could the limited human mind comprise that which transgresses the limits of his very comprehension? Neoplatonist philosophy provides Augustine with the conceptual tools to free himself of the reductionism of God to a substance and postulate a transcendental God, but this transcendental sphere is also placed beyond our understanding. Augustine describes how he is taken by despair at the skeptic impossibility of attaining the Truth that he seeks. ${ }^{15}$ Pride either leads to the false assumption of self-sufficiency in

${ }^{14}$ This, incidentally, also explains Augustine's shift in his hermeneutic approach to the Bible. Whereas at first (Augustine, 1887-1, III-v-9), he is quick to discard the bible when he finds reading it difficult, after his intellectual conversion he will put the Bible aside for a while, hoping to better understand it another time (Augustine, 1887-1, IX-v-13). No one would put aside reading a restaurant menu in order to have another go at it some other time. Pessoa's poetry, however, can be read and reread, laid aside and revisited for a better understanding. This is the beginning of hermeneutics.

15 "But now, hopeless of making proficiency in that false doctrine, even those things with which I had decided upon contenting myself, providing that I could find nothing better, I now held more loosely and negligently. For I was half inclined to believe that those philosophers whom they call Academics were more sagacious than the rest, in that they held that we ought to doubt everything, and ruled that man had not the power of comprehending any truth; for so, not yet realizing their meaning, I also was fully persuaded that they thought just as they are commonly held to do." (Augustine, 1887-1, V-x-19) 
knowledge, or to despair, in view of the fundamental unattainability of Truth.

The solution that finally offers/forces itself on Augustine, is that of an inner experience that properly speaking transgresses his appeals to comprehension. The famous scene in the orchard, where Augustine breaks down and hears voices that seem to come from nowhere and order him to pick up a book and read the first passage he finds, thus opening up the space required for Revelation and his subsequent conversion, perfectly illustrates this transgression of comprehension. What is lacking in a purely philosophical discourse, is the willingness and/or capability to assume that passive receptive attitude that Scripture would require, much like in the admiration of a work of art. The epistemological evil of pride and its slide into despair stand in the way of this acknowledgment and transgression of comprehension.

This same epistemological transgression appears to permeate the entire Confessions when we consider the intention and strategy of the book. Contemporary French phenomenologist JeanLuc Marion offers us such a reading in his Au lieu de soi. According to Marion, the confessions constitute an interaction or dialogue on different levels. (Marion, 2008, pp. 66-74) At first, there is the confession of Augustine to God, whom he addresses directly, in the second person.
This confession of sins is simultaneously accompanied by the confession as eulogy of God, an expression of the fundamental precedence of God over man. It is for this reason that Augustine repeatedly quotes and paraphrases the Bible, as the word of God precedes the word of man - including the concepts of the philosophers. A second relation is that between Augustine and his readers. A confession can only be a confession, as praise can only be praise, if there are witnesses. The reader is a witness to Augustine's confession, sometimes even personally addressed or implored - thus showing the two-directional functioning at work also in this second relation: both a testimony and an appeal. The third relation Marion distinguishes is that between the reader and God. In other words, Augustine does not attempt to argue in favor of a certain truth, such as a philosopher would do. Instead, Augustine attempts to bring us into a personal relationship with God, much the same as he himself has encountered. Thus, as Marion shows us, the Confessions show a shift from a mere locutionary (to pronounce) work, to an illocutionary (to move us) writing, and finally a perlocutionary (to make us act) appeal. It is with this third step that the Confessions - and indeed many of Augustine's works, both from his earlier period and during his many years as a bishop - show their true intention. That 
intention is neither to inform us, nor to convince or even to move us, but to make us act. Marion's phenomenological study thus leads to the starting point of the ethical question of how to live.

\section{Moral Evil: Sex (Cupiditas)}

Before moving to the question of how to live, one more form of evil requires attention. As mentioned above, Augustine distinguishes between evils we suffer (das Schlechte), and evils we commit (das Böse). We have mentioned death as the embodiment of evil we suffer, whereas pride is one form of evil we commit, albeit on an epistemological level and in a partly unconscious way, as it affects our perception of world and of self. Pride is an evil both of and out of ignorance. But there is also that evil that we commit knowingly and willingly, that human tendency to doing evil deeds.

It may be noted that, prior to Augustine, ancient Greek and Roman thought offered little to solve the enigmatic possibility of acting contrary to the good. Socrates proposed a profound anthropological optimism, in which it is impossible for any person to perform an evil act willingly and knowingly. Evil can only be understood as an act of ignorance. ${ }^{16}$ For example, I may be unaware of the universal truth that stealing is ${ }^{16}$ This idea is implicit in Plato, Gorgias 469e-479e

\footnotetext{
${ }^{17}$ This is elaborated in Aristotle, Nicomachean Ethics 1146b25-1149a20
}

wrong. Once I comprehend this truth, I will no longer steal. Aristotle expands on this proposal, including the possibility to deceive oneself. One can act wrongly when, even if one knows what would be the right thing to do in general, one fails to apply the general rule to a particular case. ${ }^{17}$ For example, I know that stealing is wrong, and I know these pears are not mine and so I should not steal them, but my hunger temporarily distracts my mind from this universal truth to another truth, that pears can still my hunger. Augustine, however, when stealing the pears, as recounted in the famous passage in his Confessions, knows that stealing is wrong, and he knows that this rule applies to what he is doing. To make matters worse, he is not even hungry. On the contrary, Augustine recognizes that hitherto unheard-of possibility to do wrong, knowingly and willingly, for the sake of doing wrong. "Yet had I a desire to commit robbery, and did so, compelled neither by hunger, nor poverty through a distaste for well-doing, and a lustiness of iniquity. For I pilfered that of which I had already sufficient, and much better. Nor did I desire to enjoy what I pilfered, but the theft and sin itself. [...] Those pears truly were pleasant to the sight; but it was not for them that my miserable soul lusted, for I had abundance 
of better, but those I plucked simply that I might steal. For, having plucked them, I threw them away, my sole gratification in them being my own sin, which I was pleased to enjoy." (Augustine, 1887-1, III-iv-9 - III-vi-12) It is this particularly human capacity to willingly and knowingly commit evil acts that haunts Augustine. Particularly human in that it is that trait which he recognizes even in the smallest children, as he rhetorically asks "I pray you, O my God, where, Lord, or when was I, Your servant, innocent?" We receive no answer, for, as he continues, "I pass by that time, for what have I to do with that, the memories of which I cannot recall?" (Augustine, 1887-1, I-vii-13)

Underlying this desire to do evil simply for doing evil, is the desire. As we shall see shortly, desire is the unifying principle for all human beings. All human beings desire. The error occurs in that we get confused over what it is that we desire. Nowhere is this desire more clearly expressed than in Augustine's pursuit of the sin of concupiscence. Even when, at an intellectual (epistemological) level, he has already acknowledged the Christian Truth and knows in which direction to take his life, he declares himself incapable of freeing himself of the desires for the flesh and earthly pleasures. ${ }^{18}$ Despite all his attempts to free himself from the evils of Manichaean metaphysics, from philosophical pride; his earthly desires do not seem to let him go, not before that moment of divine intervention that make up the final and decisive conversion of Augustine toward God.

Basically, the problem of desiring earthly goods, is that we are desiring goods which, as mentioned before, are marked by privation, which is to say are they only relative goods. This means that we may and will lose whatever goods we might obtain. As mentioned before, death not only menaces our own existence, it also snatches away those that we love. Death is the paradigmatic translation of the transitory nature of the lesser goods that make up the world. These lesser goods are just that: lesser goods. They are not in themselves evil, for as creations of God, delicious foods, beautiful music, the female body, they are all good insofar as they exist. However, none of these goods is the Supreme Good. They will wither and perish and, we will be constantly experiencing the menace of their disappearance.

Much in the same manner as natural evil, on a metaphysical level, was

\footnotetext{
18 "But I, miserable young man, supremely miserable even in the very outset of my youth, had entreated chastity of You, and said, Grant me chastity and continency, but not yet. For I was afraid lest You should hear me soon, and soon deliver me from the disease of concupiscence, which I desired to have satisfied rather than extinguished." (Augustine, 1887-1, VII-vii-17)
} 
explained as the privation of good, evil acts, Augustine proposes, are in fact acts identified by privation, failed acts. When we give in to our lusts, we are in fact failing to act. To understand this, we can refer to Augustine's use of the classical theory of natural movement and rest. ${ }^{19}$ This theory state that all objects have a natural point of rest, a natural belonging. For example, rocks have a natural tendency to fall to the ground, flames have a natural tendency to reach upward. When unhindered, the rock will go to the ground, the flames will rise up. It is possible to keep the rock or the flame from moving toward their natural place of rest by impeding them from acting as they naturally would. We could, for example, suspend the rock by a rope, or smother the flame under a blanket. In these cases, the objects are not infact; they are impeded to act.

Now, Augustine starts his dialogue on happiness observing that "we are body and soul" (Augustine, 1948, II-7). The same basic principle that distinguishes motion and (unnatural) motionlessness in objects also applies to the motions of the soul. The natural motion of the soul is upward, that is to say, towards the Supreme Good. ${ }^{20}$ It is only when the soul is impeded from its natural motion

${ }^{19}$ See for example Aristotle, Physics IV, 184a10-192b4

20 "I will soar, then, beyond this power of my nature also, ascending by degrees unto Him who made me." (Augustine, 1887-1, X-viii-12) that it will go into another direction, for example, toward concupiscence and sin. Thus, when our desires are directed toward the lesser goods, we are in fact not fully acting, or failing to act in the full sense of the term. Acting wrongfully is perversion in that it is a deviation from the natural way for a soul to act, in the same way as for an object to act contrary to its natural way of acting is being impeded to act, and as for a good that is not supremely Good to be determined by its privation of something.

Now, we have seen above that the metaphysical answer to the metaphysical problem of evil is not, for Augustine, the central issue at stake: it is its moral consequence. While among the Manicheans, Augustine declares that "it still seemed to me that it was not we that sin, but that I know not what other nature sinned in us. And it gratified my pride to be free from blame and, after I had committed any fault, not to acknowledge that I had done any-that You might heal my soul because it had it, and to accuse something else (I know not what) which was with me, but was not I." (Augustine, 1887-1, V-x-18).

This ethical turn is not to entirely dismiss any metaphysical reading of Ausinned against You; but I loved to excuse 
gustine. On the contrary, we can summarize by retaining three of its most important contributions. In the first place, the postulation of a supremely good and omnipotent - as well as transcendent-God. This presupposition remains at the basis of Augustine's thought. And, regarding man as an ethical actor, it will recur in the form of the (theological) difficulty, if not impossibility, of solving the problem of evil without divine help, i.e. without the grace of God. A second point to keep in mind is that the world and all beings in it are good. In the eyes of God, there is strictly speaking no evil in nature, only lesser goods. ${ }^{21}$ Thirdly, if God is considered all-powerful and supremely good, and if the worldly order is not in itself evil, but only less good, then evil falls upon the shoulders of man. This man is a free agent, choosing willingly and knowingly to do evil. That was the gift of God to Adam. To further delve into these and other matters from a metaphysical point of view is a valuable exercise, but not one that we wish to endeavor. It does, however, lead to the ethical issue of a free agent required to act and live.

\section{Metaphysical, Epistemological And Moral Evil}

Linking these three faces of evil together, we can summarize by pointing out that, in all three cases, the same root problem is that we attach too much value to matters that do not deserve the value we attach to them. Whether it is our own life, our pride (reflected in the esteem of others), or the temptations of the flesh, in all three cases, we consider as good things which are in fact inferior. The result, in all three cases, is to fail to act according to the natural motion of the soul.

This is not to say that these three faces of evil are in themselves evil, on the contrary. Death is only an evil to us who suffer them. From God's point of view, these and other natural evils are not in fact evils but part of a whole. This is the aesthetic argument that Augustine ventures to formulate in an ontological frame against the Manicheans. "And to You is there nothing at all evil, and not only to You, but to Your whole creation; because there is nothing without which can break in, and mar that order which You have appointed it."22

\footnotetext{
21 "And to You is there nothing at all evil, and not only to You, but to Your whole creation; because there is nothing without which can break in, and mar that order which You have appointed it. But in the parts thereof, some things, because they harmonize not with others, are considered evil; whereas those very things harmonize with others, and are good, and in themselves are good." (Augustine, 1887-1, VII-xiii-19)

${ }^{22}$ Augustine, 1887-1, VII-xiii-19
} 
The second case, pride, in itself is indeed an evil, and Augustine points to its dangers in his Confessions. ${ }^{23}$ But pride, along with the despair it could lead to, when brought back to its roots in the philosophical investigations Augustine himself has gone through, may have its place in a necessary development toward the understanding of the Good. Reading the Neoplatonic philosophical texts provided Augustine with the conceptual framework he needed to surpass the Manichean errors. The limited conceptual truths of philosophy and the self-conscious confrontation with the limits of our understanding can motivate us to hide in the short-sighted answers of science (curiositas), or plunge us into a skeptic despair. But as an intermediate stage, this was a necessary step. Indeed, the risk is much greater in passing from revelation to philosophy than the other way around. One who moves from revealed truths to philosophical concepts may risk mistakenly seeing the truth of revelation in the limited philosophical concepts. By first passing through that philosophical search for truth, we can subsequently appreciate revelation more fully.

Third was the issue of concupiscence or the temptations of the flesh. Desire in man is, in itself, not an evil. On the contrary: every man desires. Now, what is it that he desires? Augustine's answer: to be happy. Thus we come to the properly ethical dimension of Augustine's work: his appeal to live a good life. This appeal makes up the perlocutionary dimension of the Confessions, and it is at the heart of the dialogue De Beata Vita.

\section{BEATA VITA}

We come then to the question of the good life. What should we do, how should we live our lives? Much as Aris- totle places the desire for knowledge in the heart of men ${ }^{24}$, Augustine also sees man as determined by desire. The fun-

\footnotetext{
${ }^{23}$ In addition to this there is another form of temptation, more complex in its peril. For besides that concupiscence of the flesh which lies in the gratification of all senses and pleasures, wherein its slaves who are far from You perish, there pertains to the soul, through the same senses of the body, a certain vain and curious longing, cloaked under the name of knowledge and learning, not of having pleasure in the flesh, but of making experiments through the flesh. This longing, since it originates in an appetite for knowledge, and the sight being the chief among the senses in the acquisition of knowledge, is called in divine language, the lust of the eyes." (Augustine, 1887-1, X-xxxv-54)
}

${ }^{24}$ Aristotle, Metaphysics, 980a21 
damental principle for Augustine is the desire - for what? For happiness. "All men desire to be happy", Augustine observes (Augustine, 1948, II-10). An observation no doubt prima facie more credible than Aristotle's "all men by nature desire to know". But the apparent universal principle of man disperses as soon as the question is raised: what is happiness?

In short, the perfect life according to Augustine rests on three pillars: "solida fide, alacri spe, flagrante charitate" (Augustine, 1948, IV-35); or faith, hope and love, echoing Corinthians 13:13. These three pillars resound throughout the life and works of Augustine, each receiving much more elaborate - and more profoundly religious exploration in later works, for example in his Enchiridion or Handbook on Faith, Hope and Love. But the stem of his advice for living a good life was already present when his own conversion was still fresh and continuity with his classical predecessors was still very evident. Each of these pillars of the good life show faith, hope, and love, and reply to different aspects of the problem of evil that so preoccupied the pre-conversion Augustine.

\section{Faith}

If we persistently follow through on the phenomenological reading of the relation and intention that guides the Confessions, we can conclude that, what really matters for Augustine, is to bring his readers to a relationship with God which is to say, with the Good. However, a problem immediately presents itself. As we have seen, God is fundamentally transcendental in that He is fundamentally beyond our grasp. Beyond our grasp: not only in the sense of being beyond our understanding (irreducible to any concept -hence, incidentally, the impossibility of a purely theological reading of Augustine), but also beyond our reach. This unreachability of happiness resonates throughout the Confessions, starting with the famous phrase in the very first chapter: "You move us to delight in praising You; for You have formed us for Yourself, and our hearts are restless till they find rest in You." (Augustine, 1887-1, I-i-1) A state of rest that we can reach in this life, or only at the end of (beyond) this earthly life? To answer this, we can consider the first part of Augustine's dialogue The Happy Life, presenting a comparison of the human search for happiness with the search for a harbor. (Augustine, 1948, I-1 - 3) There are, he observes, three types of people, or three ways of conducting the search for the good life.

The harbor, Augustine states, is happiness, which to Augustine coincides with philosophy. Now, considered that philosophy is the search for truth, which, to Augustine, is the search for God, we can conclude that the harbor is in fact unattainable in this life. We are, as it were, always at sea. And while at sea, we can ei- 
ther attempt to sail towards the harbor, or we can sail out "deceived by the sea"traveling in pursuit of other ends, or in a third case, we can steady our course after having been adrift for a long time. Augustine considers himself of the third category, having passed the first thirty years of his life wandering in all the wrong directions only to change course after that fateful conversion under the fig-tree.

It seems that Augustine considers these three different options not so much as options, but rather"types of persons". We thus see to what extent, as was the case in the epistemological dependency on grace, we once again depend on God's gift to us. We "are" one of three types, and it seems to depend on something beyond ourselves to which category we belong. But this profound and highly complex issue of predestination is not what we wish to investigate here.

Although there are three "types of man", there are in fact two possible courses, the third type being a variation or combination of both. And these are, continuing in the metaphor of the sea, towards the harbor (philosophy=Truth=God), or out to sea. In one case, we set ourselves a certain goal to reach, whereas others "have chosen to proceed out into the middle of the sea and venture to journey far away from their homeland, which they then often forget." (Augustine, 1948, 1-2) But in both cases we are, and remain, out at sea. In other words, whatever course we may set, we are, as humans, out at sea, and can only determine what course we set, not whether or not we will sail. We are, so to speak, thrown into this world, and have to make do with our worldly condition. Discarding our worldly state is not an option. This includes accepting the waves and storms that we meet on our way.

It further seems that, in both cases of the captain set for the harbor and the drifter, we "belong" in that harbor: that is the "natural" destination for both the determined captain and the drifter, reminding us of the theory of natural movement and rest. Much like Odysseus, we are trying to reach our home. But unlike Odysseus, and perhaps more closely resembling Moses crossing the Red Sea, we do not know where it is exactly that we are going, we do not know what awaits us at our destination. We are not returning to a known state, but heading out to an unknown destination. We only know that that destination is the Good, although, as the Good is wholly transcendental, we are incapable of comprehending this.

Contrary to the skeptic philosophers, who continue searching for a truth that they themselves declare they can never attain, Augustine proposes the possibility to "possess God". (Augustine, 1948, III-21) This possible possession of God 
finds itself in an enduring tension with the established transcendental nature of God. Reminiscent of another metaphor involving the sea, Augustine compares the finite world with a sea, and God with a sponge, containing and permeating all finite things in its own infinity. ${ }^{25}$ Thus, God at the same time permeates all being, and finds itself as the destination towards which one is to direct oneself.

A somewhat counterintuitive consequence is that it is quite possible to be happy, even though one does not have everything one might desire. And, on the other hand, having everything you desire may not assure happiness. In the first case, the desire we have is directed at the (eternal) Good that we may not attain, but keeping it as our destination is what truly contributes to happiness. Whereas, in the second case, we may have every thing we desire, but all those things do not amount to any happiness, being constantly menaced by their loss, and, even worse, distracting us from that thing that we should be preferring. Happiness encountered in the pursuit of ends other than the natural end of what is natural to the human soul, is in fact not happiness, but a deception.

\section{Hope}

God withdraws from our knowledge, right before our gaze. In the end, we inevitably fail to comprehend Him. Does that also mean we fail to grasp the Good, or to attain happiness? The skeptic concern was that it is impossible to attain the truth, which would lead to inescapable unhappiness since, according to Augustine, unhappiness is lacking something, whereas happiness is not lacking in anything. (Augustine, 1948, IV-33) In a way, the skeptic concern is well-founded: if you persistently seek to attain truth and identify having obtained truth with happiness, then the way there will be an unhappy one. That is the mistake of the philosophers who seek to comprehend truth.

Augustine changes direction, though. Wondering how we can know God, in the Confessions he turns inward. Knowledge of God is not to be found in the world, as both Manicheans and philosophers thought, but in our own interior. In our memory, to be precise. Seeking to know God requires introspection. (Augustine, 1887-1, X-xxxiv-52)

Memory has a double paradox. On the one hand, the infinite ca-

\footnotetext{
25 "I made one huge mass of all Your creatures, distinguished according to the kinds of bodies-some of them being real bodies, some what I myself had feigned for spirits. And this mass I made huge - not as it was, which I could not know, but as large as I thought well, yet every way finite. But You, O Lord, I imagined on every part environing and penetrating it, though every way infinite; as if there were a sea everywhere, and on every side through immensity nothing but an infinite sea; and it contained within itself some sponge, huge, though finite, so that the sponge would in all its parts be filled from the immeasurable sea. So conceived I Your Creation to be itself finite, and filled by You, the Infinite." (Augustine, 1887-1, VII-v-7)
} 
pacities of our memory carry with it its own finitude. This refers to the odd phenomenon of forgetting. We have already mentioned Augustine's rhetorical question to our own infancy. Who knows what sins we committed when we were young? Although it should be somewhere in our memory, we have forgotten it. This is the beginning of the need for constant search of the interior, for example in the practice of the confession of our sins. Our memory has the strange capacity to forget. And to contain the forgotten. ${ }^{26}$

On the other hand, this finite interior gaze contains the infinite. "Great is this power of memory, exceeding great, O my God_an inner chamber large and boundless! Who has plumbed the depths thereof? Yet it is a power of mine, and appertains unto my nature; nor do I myself grasp all that I am. Therefore is the mind too narrow to contain itself. And where should that be which it does not contain of itself? Is it outside and not in itself? How is it, then, that it does not grasp itself?" (Augustine, 1887-1, X-vi- ii-15) For all its limitations and weaknesses, memory is also a step beyond our exterior context and even beyond our experience, beyond our own identity.

Augustine's analysis of memory is worthy of (and indeed has led to) much more investigation than is appropriate here. ${ }^{27}$ Returning to the issue of the good life, Augustine starts his De Beata Vita with a comparison that perfectly fits in the line of his ancient predecessors concerning such issues. After having proven that man consists of body and soul, he asks: "since we all now agree that man cannot exist without body and without soul, I ask all of you: For which of the two do we try to obtain food?" (Augustine, 1948, II7) Food is for the body, it is determined, and, making his point, Augustine states that "All bodies have by nature received a measure that they cannot exceed [...]" (Augustine, 1948, II-7) In other words, a body needs a certain amount of nutrition to function at its best, neither more, nor less. ${ }^{28}$ The same, Augustine argues, goes for the soul. Just as the body has a right measure, the soul too needs its nu-

26 "When I name forgetfulness, and know, too, what I name, whence should I know it if I did not remember it? [...] But when I remember forgetfulness, there are present both memory and forgetfulness-memory, whereby I remember, forgetfulness, which I remember. But what is forgetfulness but the privation of memory?" (Augustine, 1887-1, X-xvi-24)

${ }^{27}$ See, for example M. Heidegger, 1995

${ }^{28}$ This incidentally carries a strong criticism to any ascetic idea of radical abstinence. The philosophy - or rather, lifestyle - of the school of the cynics has been considered to have had considerable influence on the earliest Christian sects, particularly adhering the hermit ways of living, a practice Augustine was undoubtedly familiar with. 
trition- in the right amounts. In the case of the soul, nutrition consists of science, or knowledge, not of the world of things, but of that interior that could lead from the finite level of being to the infinite experience of the Good. We encounter this need for the right measure throughout the dialogue itself, where the chapters of the writing, equivalent to evenings of discussion, opens with a reference to the beautiful weather or the pleasant meal ${ }^{29}$, and closed with a "jovial moment" and proper retirement for the day. ${ }^{30}$

This is not to say, though, that Augustine would welcome inactivity as such. On the contrary: "nequitia", idleness, is the mother of all vices, whereas its opposite is the virtue "frugalitas", temperance. ${ }^{31}$ Augustine explains the term frugalitas referring to its root in fruit, observing that the task of this virtue is to bear spiritual fruit, whereas nequitia has the same root as negation, i.e. nothing. In other words, Augustine calls for modest and well-dosed activity, involvement in the right way and to the right measure - but involvement nonetheless. Inactivity is required only because, much as the experience of true beatitude shared with his mother Monica, we are not capable of maintaining that state of knowledge sought after. (Augustine, 1887-1, IX-X) Pure beatitude alone is indigestible. And we ought to avoid the nothingness of inactivity.

\section{Love}

We thus arrive at the third pillar of Augustine's good life, love - possibly the most important one, as the aforementioned verse of Corinthians confirms. Now, both "cupiditas" and "caritas" can be translated as love, and in a way, love for the flesh and love for the Good are the same: the intentional driving force behind it, the love in man is the same. What changes is not the affection itself, it is the object it aims for.

The problem that we face, is that many of us do not focus our efforts on the right destination, on the Good. While "all desire happiness", and while our "natural destination" is the Good, we may find ourselves mistaking the lesser goods for the Good. As we have seen, these lesser goods are not evils, rather they are goods that lack in comparison to the Good, goods marked by privation. We might find some short-lived illusions of happiness, constantly menaced by

\footnotetext{
${ }^{29}$ For example, Augustine, 1948, II-16

${ }^{30}$ For example, Augustine, 1948, IV-23

${ }^{31}$ Augustine, 1948, II-9. The original text reads "Etenim ipsam nequitiam matrem omnium vitiorum, ex eo quod enquidquam sit, id est ex eo quod nihil sit, veteres dictam esse voluerunt. Cui vitio quae contraria virtus est, frugalitas nominator."
} 
the negation it carries with it, or, in other words, by its natural limitations, by its deprivation in comparison to Happiness.

Augustine gives two examples of his own experience of pursuing goods that ultimately kept him, for a long time, from pursuing the Good. These are the interest for honor and pride, and the attraction of the flesh or women, which he calls concupiscence. ${ }^{32}$ Both are forms of a misdirected desire for happiness and a resulting misguided conception of the good life. Thus desire as impulse for all human endeavor is present, and the image of Augustine burning heart in hand is quite accurate: desire drives us all. But in the cases of the flesh and honor, that desire is misdirected, aiming at matters that ultimately keep us from, rather than approach us toward, happiness. How is that the case? In that the flesh and honor will one day lose their value, diminish, perish. These goods are only relative and will one day cease to show the value we once attributed to them, or even cease to be altogether. The result, of course, is that we can grow attached to lesser goods and be constantly threatened by their imminent loss.

Augustine's solution is not, as did the anchorites of his time, to turn his back on the world. Returning to the metaphor of the ship out at sea seeking to steer towards the harbor, we simply are in the world: that is a givenness we cannot change. And we will have to keep muddling through everything life throws at us, all the time keeping a steady course. And, returning to the metaphor of food for the soul, we do not try to smother our desires as perhaps the stoics would propose. Instead, much as in order to stay healthy physically, we do not stop eating, but choose to follow a healthier and more balanced diet, we rearrange our diet for the soul to make it as healthy as possible. We do not stop to think and contemplate, but instead of contemplating vanities in and for themselves (curiositas), we contemplate truths that contribute to our spiritual wellbeing.

Thus we continue to exist in and for the world, attempting to improve it and ourselves, despite, or rather in the face of, any adversities, challenges and setbacks. With that, the care for the self traversing Augustine's threefold reply to the threefold problem of evil, arrives at the care for the other. As we have seen, the entire Confessions can be seen as an attempt to bring the reader into a relationship with God. Augustine does not abandon his commitment to the world, or to philosophy as a pursuit of happiness. Nor does he abandon desire as the driving force of all human endeavor.

32 "I acknowledge that I did not fly quickly to the bosom of philosophy, because I was detained by woman's charm and the lure of honors [...]." Augustine, 1948, I-4 
After his conversion, Augustine abandons his post as a rhetoric speaker and accepts a religious post in his native Hippo. He will devote the next forty years of his life to all the tasks included in that post, from giving sermons to refuting rival sects and resolving local disputes. For a man once close to a very successful career in the highlife of the Roman Empire, this is no less than a bucketful of petty tasks. But Augustine accepts them wholeheartedly, because in these tasks he finds his love redirected, not to one person or another, but to all people, and through all people to the Good that he has encountered in God.

This explains how his longtime partner can disappear unnamed, and why only a few lines are dedicated to the death of his own son ${ }^{33}$. Because the love he channels is no longer an individual one, aimed at one person or ano- ther, but much rather a universal love, aimed not at lesser goods of this earth, that will come and go, but through them to the universal and eternal Good. It is, then, not desires in themselves that we seek to eliminate, on the contrary. Desire is universal; the desire for happiness is what determines all human beings as such. The difference lies not in the desires themselves, but in their direction, in their object. Desires aimed at lesser goods are what Augustine calls cupiditas, desires aimed at the higher good caritas. Whereas cupiditas should be combatted whenever possible for ultimately being a distraction from the good toward which we should aim, caritas turns out to be a central aspect in Augustine's proposal of the good life. The good shifts from an interpersonal good (the other) to an absolute Good (the Other, or God). Charity is desire redirected.

\section{CONCLUSION}

Augustine's idea of the good life is in some ways problematic for today's secular society. His reliance on Scripture, his doctrine of original sin permeating all mankind, his insistence of the need of divine grace, are but some of the most di- fficult elements to transmit unquestionably today. It is, therefore, little surprising that the current revival of the philosophy of the good life reverts to the classical schools, leaving Augustine aside. Nevertheless, Augustine places himself in this

\footnotetext{
33 "We took into our company the boy Adeodatus, born of me carnally, of my sin. Well had Thou made him. [...]Quickly did You remove his life from the earth; and now I recall him to mind with a sense of security, in that I fear nothing for his childhood or youth, or for his whole self." (Augustine, 1887-1, IX-vi-14)
} 
traditional inquiry of happiness, and by contrasting his proposals with his ideas about evil, we can distill some central elements still of value today.

Death, pride, concupiscence. Three fundamental aspects of evil, seen metaphysically, epistemologically, and ethically. Translating into the three pillars of Augustine's proposal for a good life: faith, hope, and love.

The red line connecting the three evils to be combatted, consists in mistaking lesser goods for higher ones, whether it be the lesser good of cupiditas for caritas, that of conceptual knowledge for insight in God through our interior, or the appreciation of perishable life over that of the eternal. The investigation in these three evils leads Augustine from a metaphysical through an epistemological toward an ethical investigation. That is, the question "what is evil" requires dealing with the question "how does evil affect our perception" in order to arrive to the question "what should we do in the face of evil?" So how should we live? Three concluding practical notes.

Regarding faith: as is the case with the harbor toward which we should attempt to sail, we may never reach that harbor. The harbor might even be reached only after this life. That does not mean we cannot set our goal beyond the waves of everyday life.

Regarding our intellectual pride: we should choose well we wish to nourish our souls. To attempt to capture all the scientific truths, hoping that we will somehow find the answers to the question of the eternal, is a vain endeavor. Instead, we should turn our gaze inward and investigate ourselves, our memories, our hopes, our desires. Such intellectual enterprise should, however, not detach us from the reality we find ourselves in. Spiritual searchings can and should be dosed appropriately. And instead of taking pride in our achievements, we should remain humble and aware that these capacities are not to our own merit, but are much more a gift than an individual achievement.

Finally, instead of detaching ourselves entirely from the world, we should reorient ourselves toward the Good, through that world. Desire redirected can give upward direction to our lives, moving us to where our soul would be at rest. We thus do not detach from our human condition, but accept it as a given, with all its flaws and imperfections, challenging us to contribute to the Good within a praxis, whether it is in a fervent religious task, or in dialogues and everyday tasks and relationships.

\section{WORKS CITED}


Augustine, St. of Hippo. (1887-1). Confessions. (Transl. J.G. Pilkington, Ed. Philip Schaff). Buffalo, NY: Christian Literature Publishing Co.

Augustine, St. of Hippo. (1887-2). City of God. (Transl. J.G. Pilkington, Ed. Philip Schaff). Buffalo, NY: Christian Literature Publishing Co.

Augustine, St. of Hippo. (1887-3). Concerning the Nature of Good, Against the Manichaeans. (Transl. A.H. Newman, Ed. Philip Schaff). Buffalo, NY: Christian Literature Publishing Co.

Augustine, St. of Hippo. (1948). The Happy Life. (Transl. L. Schopp, 2008). New York: Cima Publishing Co.

Augustine, St. of Hippo. (2010). "On the Free Choice of the Will". In On the Free Choice of the Will, On Grace and Free Choice, and Other Writings. (Ed. \& Transl. P. King, pp.1126). Buffalo, Cambridge: Cambridge University Press.

Botton, Alain De. (2000). The Consolations of Philosophy. London: Penguin Group.

Evans, G.R. (1982). Augustine on Evil. (1 ${ }^{\text {st }}$ paperback, 1990). Great Britain: Cambridge University Press.

Hadot, P. (1995). Qu'est-ce que la philosophie antique? Paris: Gallimard.

Heidegger, M. (1995). Phänomenologie des religiösen Lebens: "Augustinus und der Neuplatonismus", "Die philosophischen Grundlagen der mittelalterlichen Mystik". Frankfurt am Main, Vittorio Klostermann GmbH Mackie, J.L. (1955). "Evil and Omnipotence". Mind, Vol. 64, No. 254, pp.200212.

Marion, J.-L. (2008). Au lieu de soi; L'approche de Saint Augustin. Paris: Presses Universitaires de France - Épiméthée. 